\title{
PROTECTION OF THE FINANCIAL INTERESTS OF EUROPEAN UNION IN CROATIA: RECENT DEVELOPMENTS AND OLD QUESTIONS
}

\author{
Lucija Sokanović, PhD, Assistant Professor \\ University of Split, Faculty of Law \\ Domovinskog rata 8, Split, Croatia \\ lucija.sokanovic@pravst.hr
}

\begin{abstract}
A significant phase in the protection of the financial interests of European Union has been completed within adoption of Directive (EU) 2017/1371 of the European Parliament and of the Council of 5 July 2017 on the fight against fraud to the Union's financial interests by means of criminal law, as well as the Council Regulation (EU) 2017/1939 of 12 October 2017 implementing enhanced cooperation on the establishment of the European Public Prosecutor's Office ("the EPPO"). The purpose of this paper is to determine the extent to which national criminal law is harmonized with the recent European legislation in the field of the protection of the Union's financial interests and to detect what steps should be taken in order to accomplish effective protection of EU financial interests. The establishment of the European Public Prosecutor's Office and its material competences is burdened with some important issues: vagueness in prescribing criminal offences affecting the financial interests of the Union, problems with interpretation of the terms inextricably linked offences and offences regarding participation in a criminal organization if the focus of the criminal activity of such a criminal organization is to commit any of the offences affecting the financial interests of the Union.
\end{abstract}

Keywords: financial interests of EU, fraud, active and passive corruption, misappropriation, public official, European Public Prosecutor's Office

\section{INTRODUCTION}

On 1 July 2013, Croatia became the twenty-eighth member of the European Union. The journey to full membership after the experience of bloody and devastating war in nineties started in 2001 by signing the Stabilization and Association Agreement and continued by applying for membership in 2003. The candidate status was granted to Croatia in 2004, and in December 2011 the Treaty of Ac- 
cession was signed. On the state referendum in January 2012, 66\% of citizens declared themselves in favor of Croatian membership of the European Union. ${ }^{1}$

In 2007, quite far before accession, the protection of the European Union's financial interests was integrated into Croatian Criminal Code for the first time by two new incriminations: Special cases of fraud to the detriment of the European Union's financial interests (Article 224b) and Abuse of Authority relating the resources of the European Union (Article 292a). ${ }^{2}$ Within the fast and ambitious legislative reaction on the challenge of a new incrimination and the need to protect Union's financial interests, Croatia has presented the strong willingness to be an equal partner in EU. ${ }^{3}$ In 2008 the incriminations were an object of legislative changes, as well as in 2011, in the course of the great reform of Croatian Criminal Law. The purpose of this paper is to determine the extent to which national criminal law is harmonized with the recent European legislation in the field of the protection of the Union's financial interests and to detect what steps should be taken in order to accomplish effective protection of EU financial interests. In order to do so, strong critical evaluation of both, national and European legislation is the essential purport of the paper. Protection of the financial interests of European Union is indivisible linked to the work of the European Public Prosecutor's Office. So, the issue of effective protection of EU financial interests is further considered through the material competences of EPPO.

\section{WHAT ARE FINANCIAL INTERESTS OF THE EUROPEAN UNION?}

Financial interests of the Union means all revenues, expenditures and assets covered by, acquired through, or due to the Union budget and the budgets of the institutions, bodies, offices and agencies established under the Treaties and budgets managed and monitored by them. The definition from Article 2 (1) (a) of Directive (EU) 2017/1371 of the European Parliament and of the Council of 5 July 2017 on the fight against fraud to the Union's financial interests by means of criminal $\mathrm{law}^{4}$ is the same as in Article 2 (3) of the Council Regulation (EU) 2017/1939 of 12 October 2017 implementing enhanced cooperation on the establishment

1 Presidency and Croatia, [https://eu2020.hr/Home/Custom?code=CroatiaEU], accessed 15. May 2020

2 See Novoselec, P., Der EU-Betrug und das kroatische Strafrecht in: Đurđević, Z. (ed.), Current Issues in European Criminal Law and the Protection of EU Financial Interests, Zagreb, 2006, p. 20

3 Sokanović, L., Subsidy Fraud in Protection of Financial Interests of European Union: Achievements and Challenges, Journal of Eastern European Criminal Law, vol. 2, 2015, p. 150

4 Directive (EU) 2017/1371 of the European Parliament and of the Council of 5 July 2017 on the fight against fraud to the Union's financial interests by means of criminal law, OJ L 198, 28.7.2017 (PIF Directive) 
of the European Public Prosecutor's Office ('the EPPO'). ${ }^{5}$ It is significantly improved comparing the previous from the Convention encompassing only general budget of the European Communities or budgets managed by, or on behalf of, the European Communities. ${ }^{6}$ Inclusion of financial operations such as borrowing and lending activities as an object of protection resulted from the Position of the European Parliament adopted at first reading on 16 April 2014. ${ }^{7}$ Namely, the position of the European Parliament was that the protection of the Union's financial interests calls for a common definition of fraud covering fraudulent conduct with respect to expenditure and, revenues, assets and liabilities at the expense of the Union budget, including borrowing and lending activities. ${ }^{8}$

Consideration on EU financial interests includes two important issues: multiannual financial framework and EU budget. The multiannual financial framework (MFF) lays down the maximum annual amounts or ceilings which the EU may spend in different political fields or headings over a period of at least 5 years. The current MFF covers seven years: from 2014 to 2020. For this period the MFF enabled the European Union to spend up to EUR 1087 billion in commitments and EUR 1026 billion in payments. ${ }^{9}$ On 2 May 2018, the Commission presented a package of legislative proposals on the 2021-2027 MFF, on own resources to finance the EU budget and on linking the EU budget with the rule of law. ${ }^{10}$ Following the May 2019 European elections, the Parliament reestablished its MFF negotiating team, confirmed its determination to reach an agreement as soon as possible, and urged the Council to immediately intensify the interinstitutional talks. ${ }^{11}$ What has been done so far lists Sapala as follows: In December 2019,

5 Council Regulation (EU) 2017/1939 of 12 October 2017 implementing enhanced cooperation on the establishment of the European Public Prosecutor's Office ('the EPPO'), OJ L 283, 31.10.2017 (EPPO Regulation)

6 Convention drawn up on the basis of Article K.3 of the Treaty on European Union, on the protection of the European Communities' financial interests, OJ C 316, 27.11.1995, pp. 49-57 (PIF Convention)

7 Position of the European Parliament adopted at first reading on 16 April 2014 with a view to the adoption of Directive 2014/.../EU of the European Parliament and of the Council on the fight against fraud to the Union's financial interests by means of criminal law, [https://www.europarl.europa.eu/ sides/getDoc.do?pubRef=-//EP//TEXT+TA+P7-TA-2014-0427+0+DOC+XML+V0//EN], accessed 18. May 2020

8 See Am. 3

9 European Commission, EU Budget 2018, Financial Report, European Union 2019, [https://ec.europa. eu/info/sites/info/files/about_the_european_commission/eu_budget/financial_report_web.pdf], p. 13, accessed 18. May 2020

10 Sapala, M., Multiannual Financial Framework for the years 2021-2027 and the New Own Resources, [https://ec.europa.eu/commission/publications/factsheets-long-term-budget-proposals_en], accessed 18. May 2020

11 Ibid. See European Parliament resolution of 10 October 2019 on the 2021-2027 multiannual financial framework and own resources: time to meet citizens' expectations (2019/2833(RSP)) 
the Finnish Presidency presented a negotiating box (document including issues, which need to be addressed during the negotiations and require political guidance from EU leaders) the first time, including figures. On 20 February 2020, President Charles Michel organized a special European Council to discuss the next long-term budget. ${ }^{12}$ The starting point for negotiations was a new version of the negotiating box. However, the two-day negotiations ended without an agreement and without determining the calendar for the next steps or meetings. Given the lack of progress in the MFF negotiating process, the European Parliament political group leaders decided to freeze negotiations on sectorial legislation related to the new MFF until the Council agrees a full negotiating mandate. Moreover, in March 2020, the Members called on the Commission to prepare, by 15 June, a contingency plan with a view to providing a safety net to protect the beneficiaries of Union programmes by ensuring continuity of funding and implementation, should agreement on the 2021-2027 MFF not be reached in time to enter into force on 1 January 2021. This possibility is provided for in Article 312(4) TFEU. The work on new MFF must be seen through the wider specter on consideration the future of Europe. The UK's decision to withdraw from the EU, as well as the challenges created by the consequences of the economic crisis, the migration crisis and terrorist threats, have prompted debate on the EU's role. ${ }^{13}$ While new needs are emerging, existing budgetary priorities, such as support for young people, education, employment, research and innovation and combating climate change, remain relevant or have even grown in importance. ${ }^{14}$

When looking into figures of the EU budget 2019, the expenditure totals EUR 165605645322 in commitment appropriations and EUR 148198939744 in payment appropriations, representing a variation rate of $+3,05 \%$ and of $+2,37$ $\%$ respectively by comparison with the 2018 budget. ${ }^{15}$ Smart and inclusive growth amounts to 67556947 173, Sustainable growth: natural resources 57399857 331, Security and citizenship 3527434 894, Global Europe 9358295 603, Administration 9944904743 , Special instruments 411500 000. Budgetary revenue totals EUR 148198939744 . The uniform rate of call for the VAT resource is 0,0 $\%$ (except for Germany, Netherlands and Sweden for which the rate of call for the period 2014-2020 has been fixed at 0,15\%) whilst that for the GNI resource is $0,6512 \%$. Traditional own resources account for $14,49 \%$ of the financing of the

$12 \quad$ Ibid.

13 Parry, M.; Sapala, M., Post-2020 MFF and own resources, Ahead of the Commission's proposal, [https:// www.europarl.europa.eu/RegData/etudes/BRIE/2018/620240/EPRS_BRI(2018)620240_EN.pdf], accessed 18. May 2020

14 Ibid.

15 Definitive adoption (EU, Euratom) 2019/333 of the European Union's general budget for the financial year 2019, OJ L 67/1, 7.3.2019 
budget for 2019. The VAT resource accounts for $11,97 \%$ and the GNI resource for $72,26 \%$. Other revenue for this financial year is estimated at EUR 1894392 $136 .{ }^{16}$

The prerequisite for the proper transposition of the PIF Directive is precisely determined object of fraud. ${ }^{17}$ The Croatian Criminal Code does not prescribe in that sense definition of EU financial interests. ${ }^{18}$ Why is this definition not necessary? Because, it is prescribed in the EPPO Regulation in the same manner as in PIF Directive, and according Article 288 of the TFEU, a regulation has general application, it is binding in its entirety and directly applicable in all Member States. ${ }^{19}$ Though, it would be fair to say that in Republic of Croatia, the protection of EU's financial interests is stipulated in Article 114a of the Budget Act ${ }^{20}$ and within Government Regulation on the institutional framework of the system for combating irregularities and fraud (AFCOS). ${ }^{21}$

\section{CRIMINAL OFFENCES WITH REGARD TO FRAUD AFFECTING THE UNION'S FINANCIAL INTERESTS}

The PIF Directive lays down two groups of criminal offences with regard to fraud affecting the financial interests of the European Union (Title II): (1) Fraud affecting the Union's financial interests and (2) other criminal offences affecting the Union's financial interests. ${ }^{22}$

\subsection{Fraud affecting the Union's financial interests}

Fraud affecting the financial interests of the European Union differs according to the object of the offence and the modalities of commission. With regard to

16 All data are taken from previously quoted Definitive adoption. See also, Report on Budgetary and Financial Managment of the European Commission, Section III of the Budget, Report pursuant to Art 249 of the financial Regulation for the financial year 2019,

[https://www.europarl.europa.eu/RegData/etudes/BRIE/2018/620240/EPRS_BRI(2018)620240_ EN.pdf], accessed 20. May 2020

17 Sokanović, L., Materijalna nadležnost Ureda europskog javnog tužitelja - hrvatska perspektiva, Hrvatski ljetopis za kaznene znanosti i praksu, Zagreb, vol. 26, no. 2, 2019, p. 674

18 Criminal Code, Official Gazette 125/11, 144/12, 56/15, 61/15, 101/17, 118/18, 126/19 (CC)

19 Consolidated Versions of the Treaty on European Union and the Treaty on the Functioning of the European Union, OJ C202/1, 7.6.2016 (TFEU)

20 Official Gazette 87/2008, 136/12

21 Official Gazette $144 / 13$. AFCOS is a system through which the coordination of legislative, administrative and operative activities is implemented with the purpose of protecting the financial interests of the European Union and direct cooperation with the European Antifraud Office (OLAF)

22 The paper in this part is based on the author's previously published paper from the note 15 
the object of the offence, there are fraud affecting the Union's financial interests in respect of (a) non-procurement-related expenditure; (b) procurement-related expenditure; (c) revenue other than revenue arising from VAT own sources referred to in point (d) and (d) revenue arising from VAT own resources. In this sense, the original division from the PIF Convention based on fraud in relation to expenditures and revenues is specified. With regard to modalities of commission, the Directive makes it clear that this fraud can be committed by any act or omission, so it can be delicta comissiva as well as delicta omissiva. However, in further determining, the modality of the commission and the effect are combined: (1) the use or presentation of false, incorrect or incomplete statements or documents; (2) non-disclosure of information, thereby violating a particular obligation; (3) misapplication of funds or assets for purposes other than those for which they were originally granted; (4) misapplication of a legally obtained benefit; (5) presentation of correct VAT-related statements for the purposes of fraudulently disguising the non-payment or wrongful creation of the rights to VAT refunds. When it comes to fraud in respect of non-procurement-related expenditure from Article 3 (2)(a), as well as to fraud in respect of procurement related expenditures from $\mathrm{Ar}$ ticle 3 (2)(b), the prescribed effects are misappropriation or wrongful retention of funds or assets. Prescribed effect for fraud in respect of revenue other than revenue arising from VAT own resources in Article 3 (2)(c) is an illegal diminution of the resources. The prescribed effect of fraud in respect of revenue arising from VAT own resources is the diminution (not illegal!) of the resources. It is clear that these frauds are material criminal offences with the exceptions of Article 3 (2)(a) iii and Article $3(2)(d)$ iii. $^{23}$

The Draft Act to Amend the CC states that the analysis of the PIF Directive "show that national criminal legislation is already in line with the requirements set by the Directive. In this regard, the criminal offences under Article 3 PIF Directive which protect the financial interests of the European Union according to their legal description correspond to the following criminal offences: Tax or Customs Evasion (Article 256 of the CC), Subsidy fraud (Article 258 of the CC) and Fraud in Business Operations Article 247 of the CC)." ${ }^{24}$ Before the compliance analysis itself, two important issues should be pointed out: first, the PIF Directive established minimum rules regarding the definitions of criminal offences and sanc-

23 Material criminal offences require the occurrence of a certain change in the external world, which may be spatially and temporally separate from the act of committing. These criminal offences are completed only when the stated consequence occurres. Kurtović Mišić, A.; Krstulović Dragičević, A., Kazneno pravo (Temeljni pojmovi i instituti), Faculty of Law, University of Split, 2014, p. 104

24 The Draft Act to Amend the Criminal Code, 2018, p. 2, [https://esavjetovanja.gov.hr/ECon/MainScreen?entityld=7635], accessed 25. May 2020 
tions; secondly, the identity of the nomenclature and the nature of the offenses is not necessary - criminal conduct under the Directive may be classified in national law as another type of criminal offence. ${ }^{25}$ Therefore, the analysis of the offence should be substantive and concrete, not superficial.

\subsubsection{Fraud in respect of non-procurement-related expenditure}

Fraud in respect of non-procurement-related expenditure corresponds in relation to the modalities of commission to the Convention fraud (Article 1 (1)(a). The Subsidy fraud from Article 258 (1) of the Croatian CC, in comparison with the aforementioned offences, contains an additional subjective feature: acting of the perpetrator with the aim of obtaining state aid for himself or another, which results in a narrowing of the criminal liability. However, in relation to the modalities of the offence from Article 1 (a)(i), (ii) of the PIF Directive, it does not contain the objective feature of the offence consisting in misappropriation or wrongful retention of funds or assets or damage. The Subsidy fraud from Art 258 of the CC encompasses in this way a wider scope of legal protection in relation to the PIF Directive.

\subsubsection{Fraud in respect of procurement-related expenditure}

Every year public authorities in the EU spend around 14\% of GDP on public procurement that amounts to more than EUR 1.9 trillion. ${ }^{26}$ The Public Sector Directive defines procurement as the acquisition by means of a public contract of works, supplies or services by one or more contracting authorities from economic operators chosen by those contracting authorities, whether or not the works, supplies or services are intended for a public purpose. ${ }^{27}$ In Croatia, a public procurement contract is a payment contract concluded in writing between one or more economic operators and one or more contracting authorities, the subject of

25 The draft Directive has been criticised because it was expected to introduce a „very minimalistic degree of minimum harmonisation", so there was a fear that the European panorama of substantive criminal law would remain fragmented. Vervaele, J. A. E., The material scope of competence of the Eueopean Public Prosecutor's Office: Lex uncerta and unpraevia?, ERA Forum, 2014, p. 97. See Sicurella, R., The Material Scope of the EPPO. A Critical Overview of Treaty Provisions and Draft Proposals, in: Nowak, C. (ed.), The European Public Prosecutor's Office and National Authorities, Wolters Kluwer-CEDAM, Milan, 2016, pp. 109-137

26 European Commission, Public Procurement, [https://ec.europa.eu/info/sites/info/files/file_import/european-semester_thematic-factsheet_public-procurement_en_0.pdf], accessed 25. May 2020

27 Directive 2014/24/EU on public procurement and repealing Directive 2004/18/EC, 26 February 2014, OJ L 094, 28.3.2014, amended by Commission Delegated Regulation (EU) 2015/2170 of 27 November 2015, Commission Delegated Regulation (EU) 2017/2365 of 18 December 2017, Commission Delegated Regulation (EU) 2019/1828 of 30 October 2019 
which is the performance of works, delivery of goods or provision of services. ${ }^{28}$ Why has public procurement expenditure become the focus of the PIF Directive? The explanation can be found in the OLAF data, which support the claim that public procurement is particularly vulnerable to fraud and irregularities: $20 \%$ of all reported irregularities in the period 2011-2016 were associated with violations of public procurement rules, as well as $30 \%$ of all reported (irregular) financial amounts. ${ }^{29}$ The reasons were numerous: unclear or complicated applicable national public procurement laws that are difficult to apply, lack of administrative capacity and expertise of authorities who are to implement the rules in a coherent and consistent way, insufficiently qualified members of the evaluation committees (especially in complex infrastructure tenders), inadequate level of audits, controls and checks conducted by the regulatory authorities, corruption with an increasing trend to use off-shore accounts in order to hide the proceeds of such crimes. ${ }^{30}$

The criminal offence in Croatian CC directly related to public procurement is Misuse of Public Procurement Procedures under Article 254. However, this offence covers a very narrow sphere of criminal conduct; the perpetrator is a person who submits as part of a public procurement procedure a bid based on a prohibited agreement between economic entities, the aim of which is that the contracting authority accepts a certain bid. ${ }^{31}$ Can the criminal offence of Subsidy fraud be applied to that conduct? While the first two forms of the offence from Article 3 (2)(b)(i)(ii) essentially coincide with the Subsidy fraud referred to in Article 258 (1) of the CC, ${ }^{32}$ it is clear that the third modality of the offence under the PIF Directive presents a narrowing of the criminal liability compared to the third modality of the Subsidy fraud. Namely, the misapplication of the funds or assets for purposes other than those for which they were originally granted must be of that kind that damages the Union's financial interests. Does this mean, given

28 Public Procurement Act, Official Gazette 120/16. Article 3 paragraph 32

29 European Commission, OLAF, Fraud in Public Procurement; A collection of Red Flags and Best Practices, Ref. Ares(2017)6254403 - 20/12/2017, p. 3. [https:/lec.europa.eu/sfc/sites/sfc2014/files/sfc-files/ Fraud\%20in\%20Public\%20Procurement_final\%2020.12.2017\%20ARES\%282017\%296254403. pdf], accessed 25. May 2020.

30 Ibid.

31 Criminal offence of Unlawful Favoritism from Article 292 is of great significance as well. Offence is committed by a public official or responsible person who on the basis of an agreement demonstrates favoritism towards an economic entity by adapting public procurement terrns and conditions or who awards a contract to a tenderer whose tender is contrary to the terms and conditions set out in the bid documentation. The same offence exists when a public official or responsible person who abuses his or her position or authority by demonstrating favoritism in the award of contracts or in taking on or negotiating deals toward his or her activity or the activity of persons with whom he or she is linked in terms of vested interests

32 With exception to the prescribed effect 
that the Directive establishes minimum rules, that national legislation needs to be changed in direction of reducing criminal liability? Such a solution in the PIF Directive abandoned the previous Convention solution, which did not contain the feature of causing damage to the Union's budget, while finding the protective good of this form of fraud in the Union's freedom to dispose of its own resources. ${ }^{33}$ Furthermore, although the offence from Article 258 of the CC contains a special subjective feature - "the aim that he or she or another person receives a state subsidy", the PIF Directive now introduces a special subjective feature when it comes to fraud in respect of procurement-related expenditure: "at least when committed in order to make an unlawful gain for the perpetrator or another by causing a loss to the Union's financial interests". All the above points to the conclusion that in order to transpose the PIF Directive, it is necessary to introduce into Croatian criminal legislation a new offence of Fraud in public procurement which would criminalize the conduct referred to in (3)(b). The use of the term "at least" refers to the freedom of the Republic of Croatia as a Member State to independently decide whether to incorporate the special subjective feature into the essence of the offence.

\subsubsection{Fraud in respect of revenue other than revenue arising from VAT own resources}

Fraud from Article 3 (2)(c) of the PIF Directive in relation to the modalities of commission corresponds to the Convention fraud referred to in Article 1 (1)(b). When comparing this offence to Tax or Customs evasion under Article 256 of the CC, it can be concluded that national offence covers all forms of criminal conduct under the PIF Directive, with the exception of the term "illegal" reduction of budget funds in prescribing the consequences of the offence.

\subsubsection{Fraud in respect of revenue arising from VAT own resources}

PIF Directive differentiates fraud in respect of revenue other than revenue arising from VAT own resources and fraud in respect of revenue arising from VAT own resources. Where does this change in relation to the PIF Convention come from? The EU budget is financed from the Union's own resources in accordance with Article $211 \mathrm{TFEU}$, and own resources are as follows: traditional own resources: resulting mainly from customs duties and sugar levies, VAT-based own resources: resulting from a uniform rate of $0.3 \%$ applied to the value added tax base of each member state, with the taxable VAT base being

33 See Đurđević, Z., Konvencija o zašttiti financijskih interesa Europskih zajednica - nastanak, sadržaj $i$ implementacija, Hrvatski ljetopis za kazneno pravo i praksu, vol. 14, no. 2, 2007, p. 8 
capped at 50\% of GNI for each country, GNI-based own resources : resulting from a uniform rate applied to the gross national income of member states; this rate is adjusted every year in order to balance revenue and expenditure. ${ }^{34}$ Therefore, VAT-based funds should represent the financial interests of the EU as they are an integral part of the Union budget (revenue). However, it was precisely the question of whether the PIF Convention covers VAT fraud that has become one of the most controversial in the process of negotiating and adopting the PIF Directive. ${ }^{35}$ Namely, the Commission and the Parliament strongly advocated the inclusion of VAT fraud, unlike the Council, which justified its opposition by stating that VAT is an exclusively national matter and that VAT fraud damages occur only in the Member States where they are committed. ${ }^{36}$ Just when the negotiations were at a standstill, the European Court of Justice contributed to the clarification of this issue with the so-called Taricco's decision. ${ }^{37}$ In the Case Åklagaren v. Hans Akkerberg Fransson, the Court has previously held that VAT presents the Union's own resources and that there is a direct link between the collection of VAT by Member States and the availability of corresponding VAT resources to the EU budget. ${ }^{38}$ In the Taricco decision, the Court equated VAT revenue with the Union's financial interests, stating: "Although the Member States have freedom to choose the applicable penalties - which may take the form of administrative penalties, criminal penalties or a combination of the two - in order to ensure that all VAT revenue is collected and, in so doing, that the financial interests of the European Union are protected in accordance with the provisions of Directive 2006/112 and Article 325 TFEU, criminal penalties may nevertheless be essential to combat

34 European Council, Own resources for 2014-2020, [https://www.consilium.europa.eu/en/policies/ eu-budgetary-system/eu-revenue-own-resources/2014-2020/], accessed 26. May 2020

35 Juszczak, A.; Sason, E., The Directive in the Fight against Fraud to the Union's Financial Interests by Means of Criminal Law (PFI Directive): Laying Down the Foundation for a Better Protection of the Union's Financial Interests? Eurcrim vol. 2, 2017, p. 82

36 Ibid. See, Ballegooij van, W., European Public Prosecutor's Office - A View on the State of Play and Perspectives from the European Parliament, in: Geelhoed, W. et al. (eds.), Shifting Perspectives on the European Public Prosecutor's Office, Springer, 2017, p. 32

37 Ibid. Case C-105/14, Ivo Taricco et al. [2015] ECR, Judgement of the Court (Grand Chamber) of 8 September 2015. See Staffler, L., Towards a New Chapter of the Taricco Saga, EuCLR, vol. 9, no. 1, 2019, pp. 59-81; Pinelli, C., Are Courts Engaged in a "Dialogue“ on financial matters?, in: Belov, M. (ed.), Judicial Dialogue, Elven International Publishing, 2019, pp. 111-126; Ferro, M.S., ECJ on Taricco II: a game changer? The primacy and effectiveness of EU law take a serious hit, 2017, [https://www. linkedin.com/pulse/ecj-taricco-ii-game-changer-primacy-effectiveness-eu-law-sousa-ferro/], accessed 27. May 2020

38 Case C-617/10, Åklagaren v Hans Åkerberg Fransson [2013] ECR, $\$ 26$. As well as Case C-539/09, European Commission v Federal Republic of Germany, [2011], ECR, $\$ 72$. Vilas Álvarez, D., The Material Competence of the European Public Prosecutor's Office, in: Bachmaier Winter, L. (ed.), The European Public Prosecutor's Office: The Challenges Ahead, Legal Studies in International; European and Comparative Criminal Law 1, Springer, 2018, p. 34 
certain serious cases of VAT evasion in an effective and dissuasive manner." ${ }^{39}$ The position is even more explicitly stated in paragraph 41 :

„The concept of 'fraud' is defined in Article 1 of the PFI Convention as 'any intentional act or omission relating to ... the use or presentation of false, incorrect or incomplete statements or documents, which has as its effect the misappropriation or wrongful retention of funds from the general budget of the European [Union] or budgets managed by, or on behalf of, the European [Union]'. The concept therefore covers revenue derived from applying a uniform rate to the harmonised VAT assessment bases determined according to EU rules. That conclusion cannot be called into question by the fact that VAT is not collected directly for the account of the European Union, since Article 1 of the PFI Convention specifically does not lay down such a condition, which would be contrary to that convention's objective of vigorously combatting fraud affecting the European Union's financial interests."

The compromise of the previously stated opposing views was realized by the fourth form of fraud from the PIF Directive in Article 3 (2)(d) in connection with Article 2 (2), i.e. by instructing to criminalize only serious criminal offences against the common VAT system. This involves fraud in respect of revenue arising from VAT own resources committed in cross-border fraudulent schemes, connected with the territory of two or more Member States of the Union, and if damage of at least EUR 10 million has been caused. ${ }^{40}$ In doing so, the notion of total damage refers to the estimated damage resulting from the entire fraud scheme, both to the financial interests of the Member States concerned and to the Union, excluding interest and sanctions. ${ }^{41}$ It should be emphasized here that the assessment of the adequacy of the EUR 10 million threshold will be the subject of a report to be submitted by the Commission by 6 July 2022 to the European Parliament and the Council. ${ }^{42}$ Furthermore, the notion of serious criminal offences against the common system of VAT refers in particular to carrousel fraud, VAT fraud through missing traders and VAT fraud committed within a criminal organization, which create serious threats to the common VAT system and thus to the Union budget. ${ }^{43}$

39 $\$ 39$. On the European Court of Justice and the principle of legality, see Timmerman, M., Legality in Europe: On the principle nullum crimen, nulla poena sine lege in EU law and under the ECHR, Intersentia, 2018, p. 254-255

40 The Commission and Parliament considered the EUR 10 million threshold too high and advocated a reduction to EUR 5 million. See, Giuffrida, op. cit., note 55, p. 9

41 Recital 4 of the PIF Directive

42 See Art 18

43 Recital 4 of the PIF Directive. 
Given the notion of offence from Article 256 of the CC and the finding that Croatia has transposed the PIF Directive, the question raises of whether we have thus left the European Public Prosecutor's Office the power to prosecute VAT evasion regardless of the amount of damage caused or the involvement of the territory of two or more Member States? As national law does not provide for a restriction on serious offences against the common system of VAT, the EPPO could indeed prosecute any tax or customs evasion. ${ }^{44}$ Furthermore, tax or customs evasion under Article 256 of the CC does not cover the third modality of VAT fraud committed in cross-border fraudulent schemes: presentation of correct VAT-related statements for the purposes of fraudulently disguising the non-payment or wrongful creation of rights to VAT refunds. In this regard, it would be necessary to make appropriate amendments to the CC.

\subsection{Other criminal offences affecting the financial interests of the Union}

The Directive prescribes other criminal offences affecting the financial interests of the Union: money laundering, passive and active corruption and misappropriation. Before analyzing these criminal offences, it is necessary to define the term of public official who, according to the PIF Directive, is a perpetrator of passive corruption and misappropriation. ${ }^{45}$

A public official may be: a Union official, a national official or any other person assigned and exercising a public service function involving the management of or decisions concerning the Union's financial interests in Member States or third countries (Article 4 of the PIF Directive). In researching the reasons for introducing private persons into the concept of public officials, it was established that the European Parliament legislative resolution of 16 April 2014 on the proposal for a Directive stated that private persons are increasingly involved in the management of Union funds. ${ }^{46}$ The 2012 PIF Proposal also stated the need to include a defi-

44 In amount more than KN 20000

45 On the issue of interpreting the term official person, see Đurđević, Z., Insufficient and Irrelevant Constitutional Reasons for the Revocation of the Criminal Courts' Judgments in the INA MOL Case upon the Constitutional Complaint of the Ex-Prime Minister of Croatia, HLJKPP, vol. 25, no. 2, 2018, pp. 261 302

46 European Parliament legislative resolution of 16 April 2014 on the proposal for a directive of the European Parliament and of the Council on the fight against fraud to the Union's financial interests by means of criminal law (COM(2012)0363 - C7-0192/2012 - 2012/0193(COD)), OJ C 443, 22.12.2017, p. 984 (Am. 5): „In order to adequately protect Union funds from corruption and misappropriation, the definition of 'public official' for the purposes of this Directive therefore needs to cover also persons who do not hold a formal office, but who are none the less assigned, and who exercise, in a similar manner, a public-service function in relation to Union funds, such as contractors involved in the management of such funds." 
nition of public officials covering all relevant officials, whether appointed, elected or employed on the basis of a contract, holding a formal office, as well as persons exercising the function of providing service from government and other public bodies to citizens, or for the public interest in general, without holding a formal office, such as contractors involved in the management of EU funds. ${ }^{47}$ In line with the $5^{\text {th }}$ Amendment to the previously cited 2014 legislative resolution, the $10^{\text {th }}$ recital of the PIF Directive states: "In order to protect Union funds adequately from corruption and misappropriation, the definition of 'public official' therefore needs to cover persons who do not hold formal office but who are nonetheless assigned and exercise, in a similar manner, a public service function in relation to Union funds, such as contractors involved in the management of such funds."

Insight into the provision of Article 87 (3) of the CC, makes it clear that an official person, in addition to the itemized, is also considered a "person who in the European Union ... performs duties entrusted to persons from the previous sentence." What is doubtful in relation to the Republic of Croatia is whether the notion of "duty" from the previously cited legal provision also implies tasks, ${ }^{48}$ i.e. functions, in relation to Union funds entrusted to a (private) person, or whether the use of the notion of "duty" exclusively implies the application of the definition of public servant from Article 3 (1) of the Civil Servants Act. ${ }^{49}$ Since in the Republic of Croatia civil servants are also persons who perform IT tasks, general and administrative tasks, planning, material-financial and accounting and similar tasks in state bodies (Article 3(2), the term official person from Article 87 (3) of the CC could also be applied to private persons involved in the management of EU funds, as they perform tasks entrusted to officials in the European Union. Namely, the authorization to perform tasks of official duties should be correlated with equal (criminal) responsibility. But does such an interpretation constitute a forbidden analogy? Perhaps, however, in the interests of clarity and avoidance of doubt in practice, the term official person should be extended to any person entrusted with a public function and performing a public function involving the management of

47 Proposal for a Directive of the European Parliament and of the Council on the fight against fraud to the Union's financial interests by means of criminal law, Brussels, 11. 7. 2012. COM(2012) 363 final 2012/0193 (COD), p. 13

48 Thus, we reduce the problem of subsuming these persons under the notion of an official person to a choice between restrictive and extensive interpretation. Novoselec, P., Opći dio kaznenog prava, PRAVOS, Osijek, 2016, pp. 70-72

49 Civil servants are persons who perform tasks as their regular vocation in State bodies under the jurisdiction of said bodies as specified in the Constitution, laws, or other regulations enacted pursuant to the Constitution and laws. Art 3 of the Civil Servants Act, Official Gazette 92/05, 140/05, 142/06, 77/07, $107 / 07,27 / 08,34 / 11,49 / 11,150 / 11,34 / 12,49 / 12,37 / 13,38 / 13,01 / 15,138 / 15,61 / 17,70 / 19$ 
or decisions concerning the Union's financial interests in Member States or third countries.

\subsubsection{Money laundering}

In the case of money laundering, the definition from Article 1 (3) of Directive (EU) 2015/849 is invocated, including property derived from the criminal offences covered by the Directive. ${ }^{50}$ Money laundering in accordance with that provision includes the following activities when carried out intentionally: (a) the conversion or transfer of property, knowing that such property is derived from criminal activity or from an act of participation in such activity, for the purpose of concealing or disguising the illicit origin of the property or of assisting any person who is involved in the commission of such an activity to evade the legal consequences of that person's action; (b) the concealment or disguise of the true nature, source, location, disposition, movement, rights with respect to, or ownership of, property, knowing that such property is derived from criminal activity or from an act of participation in such an acitivity; (c) the acquisition, possession or use of property, knowing, at the time of receipt, that such property was derived from criminal activity or from an act of participation in such an activity; (d) participation in, association to commit, attempts to commit and aiding, abetting, facilitating and counselling the commission of any of the actions referred to in points (a), (b) and (c). The Draft Act to Amend the CC correctly states that money laundering from the Directive corresponds to money laundering from the provision of Art 265 of the CC. ${ }^{51}$ However, the following amendments were made to implement the recommendations of MONEYVAL from the Report on the $4^{\text {th }}$ Round of Evaluation of the Republic of Croatia on the Prevention of Money Laundering and Terrorist Financing.

\subsubsection{Active and passive corruption}

Passive corruption is for the purposes of the Directive the action of a public official who, directly or through an intermediary, requests or receives advantages of any kind, for himself or for a third party, or accepts a promise of such an advantage in order to act or refrain from acting in accordance with his duty or in the exercise of

\footnotetext{
50 Directive (EU) 2015/849 of the European Parliament and of the Council of 20 May 2015 on the prevention of the use of the financial system for the purposes of money laundering or terrorist financing, amending Regulation (EU) No 648/2012 of the European Parliament and of the Council, and repealing Directive 2005/60/EC of the European Parliament and of the Council and Commission Directive 2006/70/EC, OJ L 141, 5.6.2015, p. 73-117

51 The Draft Act, op. cit., note 24
} 
his functions in a way which damages or is likely to damage the Union's financial interests. Active corruption means the action of a person who promises, offers or gives, directly or through an intermediary, an advantage of any kind to a public official for himself or for a third party for him to act or to refrain from acting in accordance with his duty or in the exercise of his functions in a way which damages or is likely to damage the Union's financial interests. Comparing active and passive corruption from the PIF Directive with Taking and Giving a Bribe as official criminal offences from Articles 293 and 294 of the CC, brings to conclusion that national offences lack the link between commission and the consequence: “... in order to act or refrain from acting ... in a way that harms or could harm the financial interests of the Union".

\subsubsection{Misappropriation}

The last offence in this group is misappropriation. For the purposes of the PIF Directive, misappropriation is the action of a public official who is directly or indirectly entrusted with the management of funds or assets to commit or disburse funds or appropriate or use assets contrary to the purpose for which they were intended in any way which damages the Union's financial interests. Embezzlement at work from Article 233 of the CC is a classical property criminal offence committed by a perpetrator who unlawfully appropriates another person's movable property or property right that was entrusted to him or her at work. A qualified form of the offence is realized if the value of the embezzled property or property right is high, and a privileged form if their value is small and the perpetrator acted with the aim of appropriating property of such value. Therefore, in comparison of the offence from the PIF Directive with the Embezzlement in the CC, the definition of the perpetrator as a public official who is directly or indirectly entrusted with the management of funds or property is missing; in the act of commission - the commission or disbursement of funds, the use of funds contrary to the purpose for which they were intended in any way, and finally linking the commission to the consequence, which manifests itself in damaging the financial interests of the Union. The Draft Act, in the context of the harmonization of the CC with the Directive, also mentions the Embezzlement from Article 232.52 Given that the basic form of Embezzlement is committed by whoever unlawfully appropriates another person's movable property or property right that was entrusted to him or her, it is obvious that there is no transposition here either. Namely, even if the interpretation were accepted that the perpetrator could be a public official and thus embezzlement would become delicta propria instead of delicta communia, the

$52 \quad$ Ibid., p. 2 
modality of the appropriation action lacks the effect prescribed by the Directive and consists in damaging the financial interests of the Union. Accordingly, the provision on this offence has not been transposed into national criminal law at all.

\section{OFFENCES REGARDING PARTICIPATION IN A CRIMINAL ORGANISATION}

Council Regulation (EU) 2017/1939 of 12 October 2017 implementing enhanced cooperation on the establishment of the European Public Prosecutor's Office ('the EPPO') prescribes in Article 22 material competences of EPPO. EPPO is competent in respect of the criminal offences affecting the financial interests of the Union that are provided for in Directive (EU) 2017/1371, as implemented by national law, irrespective of whether the same criminal conduct could be classified as another type of offence under national law. As regards offences referred to in point (d) of Article 3(2) of Directive (EU) 2017/1371, as implemented by national law, the EPPO is only competent when the intentional acts or omissions defined in that provision are connected with the territory of two or more Member States and involve a total damage of at least EUR 10 million. But, the EPPO is also competent for offences regarding participation in a criminal organisation as defined in Framework Decision 2008/841/JHA, as implemented in national law, if the focus of the criminal activity of such a criminal organisation is to commit any of the offences referred to in Article 22 (1). The Regulation directs to "participation in a criminal organisation" as implemented in national law. As for Croatia, there is no problem, because Criminal association from Article $328 \mathrm{CC}$ is harmonized with Framework decision. ${ }^{53}$ But, it's not so simple and clear at least regarding two issues. As first, the Commission points out that the Framework Decision did not achieve the necessary minimum degree of approximation as regards directing or participating in a criminal organisation on the basis of a single concept of such an organisation. ${ }^{54}$ „An overview of the Framework Decision's transposition in the Member States points to a number of divergences, which can to a large extent be attributed to differences in the Member States' legal traditions. As such, the Commission considers that the Framework Decision enables the Member States not to introduce the concept of criminal organisation but to continue to apply existing national criminal law by having recourse to general rules on participation in and

53 Turković, K. et al., Komentar Kaznenog zakona, Narodne novine, Zagreb, 2013, pp. 5, 493. See also, Pavlović, Š., Kazneni zakon, Libertin naklada, Rijeka, 2015, p. 1351

54 Report from the Commission to the European Parliament and the Council based on Article 10 of Council Framework Decision 2008/841/JHA of 24 October 2008 on the fight against organised crime, p.11., [https://eur-lex.europa.eu/legal-content/EN/TXT/PDF/?uri=CELEX:52016DC0448\&from $=\mathrm{HR}]$, accessed 27. May 2020 
preparation of specific offences. This may have the effect of creating additional divergences in the Framework Decision's practical implementation. "55 The second problem may be assessment of the concept of the "focus of the criminal activity “. 56

\section{INEXTRICABLY LINKED OFFENCES}

The EPPO is competent for any other criminal offence that is inextricably linked to criminal conduct that falls within the scope of Article 22 (1) of the Regulation with restrictions prescribed in Article 25(3). The notion of inextricably linked offences' should be considered in light of the relevant case-law which, for the application of the ne bis in idem principle, retains as a relevant criterion the identity of the material facts (or facts which are substantially the same), understood in the sense of the existence of a set of concrete circumstances which are inextricably linked together in time and space. ${ }^{57}$ If one compares definitions of inextricably linked offences from the Preamble of the EPPO Regulation and related criminal offences from Article 3 (2) of the Europol Regulation, it is obvious that the later is more precize and much clearer. ${ }^{58}$ Namely, related criminal offences are: (a) criminal offences committed in order to procure the means of perpetrating acts in respect of which Europol is competent; (b) committed in order to facilitate or perpetrate acts in respect of which Europol is competent; (c) committed in order to ensure the impunity of those committing acts in respect of which Europol is competent. The explanation from the Recital 55 does not contribute to the clarity of the determination of inextricably linked criminal offenses: "... and the offence affecting the Union's financial interests is preponderant, in terms of the seriousness of the offence concerned, as reflected in the maximum sanctions that could be imposed. "Formulation „should have the right to exercise competence“ is applied in this case as well as ,in the case of inextricably linked offences where the offence affecting the financial interests of the Union is not preponderant in terms of sanctions levels, but where the inextricably linked other offence is deemed to be ancillary in nature because it is merely instrumental to the offence affecting the financial interests of the Union, in particular where such other offence has been committed for the main purpose of creating the conditions to commit the offence

$55 \quad$ Ibid.

56 Giuffrida, F., The European Public Prosecutor's Office: King without kingdom?, CEPS, vol. 3, 2017, p. 10

57 Recital 54 of the EPPO Regulation. For the notion of cross-border offences, see Gless, S.; Vervaele, J. A. E., Law Should Govern: Aspiring General Principles for Transnational Criminal Justice, Utrecht Law Review, vol. 9, no. 4, 2013, p. 2

58 Regulation (EU) 2016/794 of the European Parliament and of the Council of 11 May 2016 on the European Union Agency for Law Enforcement Cooperation (Europol) and replacing and repealing Council Decisions 2009/371/JHA, 2009/934/JHA, 2009/935/JHA, 2009/936/JHA and 2009/968/ JHA, OJ L 135, 24.5.2016, p. 53-114. Giuffrida, op. cit. note 55, p. 11 
affecting the financial interests of the Union, such as an offence strictly aimed at ensuring the material or legal means to commit the offence affecting the financial interests of the Union, or to ensure the profit or product thereof. " 59 Based on the presented information, it can be concluded that the interpretation of the offences, and thus work of the EPPO will be apparently significantly affected by national law. It is not difficult to predict the difficulties in the work of the EPPO due to differences in national systems. ${ }^{60}$

\section{CONCLUSION}

The academic work that preceded the adoption of the EPPO Regulation was dominated by procedural aspects. ${ }^{61}$ Protection of Union's financial interests is provided by PIF criminal offences: fraud affecting the Union's financial interests and other criminal offences affecting the financial interests of the Union, offences regarding participation in a criminal organisation if the focus of the criminal activity of such a criminal organisation is to commit offences affecting the Union's financial interests and inextricably linked offences. Those offences compose material competences of the EPPO. If we observe them through the spectre of appropriate legislation, we can say that material competence of the EPPO is determinated by the EPPO Regulation and national criminal law of Member States by transposing PIF Directive. The analysis of these offences shows that the requirements of substantive legality, which consist in the perpetrator having the right to know for which criminal offences he may be liable and which punishment may be imposed on him, have not been fully met. It cannot be considered unequivocally clear what criminal offences present material competence of the EPPO, what is indeed the content of criminal conduct, that is contrary to the principle of nullum crimen, nulla poena sine lege praevia et certa. The ambiguities in the determination of material competence are further supported by the fact that conflicts of jurisdiction between the EPPO and national competent authorities are resolved by national authorities (competent to decide on the attribution of competences concerning prosecution at national level). Such a solution has been strongly criticized by the European Parliament for advocating that the conflict be decided by an independent tribunal.

59 Recital 56. See Luchtmann, M.J.J.P., Towards a Transnational Application of the Legality Principle in the EU's Area of Freedom, Security and Justice? Utrecht Law Review, vol. 9, no. 4, 2013, pp. 11-33

60 Giuffrida, op. cit. note 55, p. 11; Vilas Álvarez, op. cit. note 37, p. 36

${ }_{61}$ Ligeti, K. (ed.), Toward a prosecutor for the European union. A comparative analysis, Volume I, Oxford, 2013; Ruggieri, F., Eurojust and the European Public Presecutor's Office: Introduction to a Historic Reform, in: Rafaraci, T.; Belfiore, R. (eds.), EU Criminal Justice: Fundamental Rights, Transnational Proceedings and the European Public Prosecutor's Office, Springer, 2019, p. 185. For the critique, see Verveale, op. cit. note 25 , p. 86 
That the Republic of Croatia has transposed the PIF Directive is undoubtedly established by the provision of Article 36 of the Draft Act to Amend the CC of 2018, which states that the CC contains provisions that are in line with the Directive (item 13). But, the analysis showed that the serious and meticulous work is ahead. The superficiality that has affected all segments of modern society has no place in the field of criminal law. The possible consequences of failures to transpose the PIF Directive are far more dangerous now than those potentially faced by Member States in implementing the PIF Convention. Namely, given that the material competence of the EPPO is based on transposition because it applies national criminal law, failures in transposition can lead to unequal treatment of EU citizens and thus jeopardize legal certainty.

\section{REFERENCES}

\section{BOOKS AND ARTICLES}

1. Bachmaier Winter, L. (ed.), The European Public Prosecutor's Office: The Challenges Ahead, Legal Studies in International; European and Comparative Criminal Law 1, Springer, 2018

2. Belov, M. (ed.), Judicial Dialogue, Elven International Publishing, 2019.

3. Đurđević, Z. (ed.), Current Issues in European Criminal Law and the Protection of EU Financial Interests, Zagreb, 2006

4. Đurdević, Z., Insufficient and Irrelevant Constitutional Reasons for the Revocation of the Criminal Courts' Judgments in the INA MOL Case upon the Constitutional Complaint of the ExPrime Minister of Croatia, Hrvatski ljetopis za kazneno pravo i praksu, vol. 25, no. 2, 2018, pp. 261-302

5. Đurđević, Z., Konvencija o zašttiti financijskih interesa Europskih zajednica - nastanak, sadržaj i implementacija, Hrvatski ljetopis za kazneno pravo i praksu, vol. 14, no. 2, 2007, pp. 921 966

6. Geelhoed, W. et al., Shifting Perspectives on the European Public Prosecutor's Office, Springer, 2017

7. Giuffrida, F., The European Public Prosecutor's Office: King without kingdom?, CEPS, vol. 3, 2017

8. Gless, S.; Vervaele, J. A. E., Law Should Govern: Aspiring General Principles for Transnational Criminal Justice, Utrecht Law Review, vol. 9, no. 4, 2013, pp. 1-10

9. Juszczak, A.; Sason, E., The Directive in the Fight against Frand to the Union's Financial Interests by Means of Criminal Law (PFI Directive): Laying Down the Foundation for a Better Protection of the Union's Financial Interests? Eurcrim, vol. 2, 2017, pp. 80-87

10. Kurtović Mišić, A., Krstulović Dragičević, A., Kazneno pravo (Temeljni pojmovi i instituti), Faculty of Law, University of Split, 2014

11. Ligeti, K. (ed.), Toward a prosecutor for the European union. A comparative analysis, Volume I, Oxford, 2013 
12. Luchtmann, M.J.J.P., Towards a Transnational Application of the Legality Principle in the EU's Area of Freedom, Security and Justice? Utrecht Law Review, 2013, vol. 9, no. 4, 2013, p. 11-33

13. Novoselec, P., Opći dio kaznenog prava, PRAVOS, Osijek, 2016

14. Nowak, C. (ed.), The European Public Prosecutor's Office and National Authorities, Wolters Kluwer-CEDAM, Milan, 2016

15. Pavlović, Š., Kazneni zakon, Libertin naklada, Rijeka, 2015

16. Rafaraci, T.; Belfiore, R. (eds.), EU Criminal Justice: Fundamental Rights, Transnational Proceedings and the European Public Prosecutor's Office, Springer, 2019

17. Sokanović, L., Materijalna nadležnost Ureda europskog javnog tužitelja - hrvatska perspektiva, Hrvatski ljetopis za kaznene znanosti i praksu, Zagreb, vol. 26, no. 2, 2019, p. 669-692

18. Sokanović, L., Subsidy Fraud in Protection of Financial Interests of European Union: Achievements and Challenges, Journal of Eastern European Criminal Law, vol. 2, 2015, p. 142-152

19. Staffler, L., Towards a New Chapter of the Taricco Saga, EuCLR, vol. 9, no. 1, 2019, pp. 59-81

20. Timmerman, M., Legality in Europe: On the principle nullum crimen, nulla poena sine lege in EU law and under the ECHR, Intersentia, 2018

21. Turković, K. et al., Komentar Kaznenog zakona, Narodne novine, Zagreb, 2013

22. Vervaele, J. A. E., The material scope of competence of the Eueopean Public Prosecutor's Office: Lex uncerta and unpraevia?, ERA Forum, 2014, pp. 85-99

\section{EU LAW}

1. Consalidated Versions of the Treaty on European Union and the Treaty on the Functioning of the European Union, OJ C202/1, 7.6.2016

2. Convention drawn up on the basis of Article K.3 of the Treaty on European Union, on the protection of the European Communities' financial interests, OJ C 316, 27.11.1995

3. Council Regulation (EU) 2017/1939 of 12 October 2017 implementing enhanced cooperation on the establishment of the European Public Prosecutor's Office ('the EPPO'), OJ L 283, 31.10.2017

4. Definitive adoption (EU, Euratom) 2019/333 of the European Union's general budget for the financial year 2019, OJ L 67/1, 7.3.2019

5. Directive (EU) 2015/849 of the European Parliament and of the Council of 20 May 2015 on the prevention of the use of the financial system for the purposes of money laundering or terrorist financing, amending Regulation (EU) No 648/2012 of the European Parliament and of the Council, and repealing Directive 2005/60/EC of the European Parliament and of the Council and Commission Directive 2006/70/EC, OJ L 141, 5.6.2015

6. Directive (EU) 2017/1371 of the European Parliament and of the Council of 5 July 2017 on the fight against fraud to the Union's financial interests by means of criminal law, OJ L $198,28.7 .2017$

7. Directive 2014/24/EU on public procurement and repealing Directive 2004/18/EC, 26 February 2014, OJ L 094, 28.3.2014, amended by Commission Delegated Regulation (EU) 2015/2170 of 27 November 2015, Commission Delegated Regulation (EU) 2017/2365 of 
18 December 2017, Commission Delegated Regulation (EU) 2019/1828 of 30 October 2019

8. European Parliament legislative resolution of 16 April 2014 on the proposal for a directive of the European Parliament and of the Council on the fight against fraud to the Union's financial interests by means of criminal law (COM(2012)0363 - C7-0192/2012 2012/0193(COD)), OJ C 443, 22.12.2017

9. European Parliament resolution of 10 October 2019 on the 2021-2027 multiannual financial framework and own resources: time to meet citizens' expectations (2019/2833(RSP).

10. Proposal for a Directive of the European Parliament and of the Council on the fight against fraud to the Union's financial interests by means of criminal law, Brussels, 11. 7. 2012. $\operatorname{COM}(2012) 363$ final 2012/0193 (COD)

11. Regulation (EU) 2016/794 of the European Parliament and of the Council of 11 May 2016 on the European Union Agency for Law Enforcement Cooperation (Europol) and replacing and repealing Council Decisions 2009/371/JHA, 2009/934/JHA, 2009/935/JHA, 2009/936/JHA and 2009/968/JHA, OJ L 135, 24.5.2016

\section{LIST OF NATIONAL REGULATIONS, ACTS AND COURT DECISIONS}

1. Civil Servants Act, Official Gazette 92/05, 140/05, 142/06, 77/07, 107/07, 27/08, 34/11, $49 / 11,150 / 11,34 / 12,49 / 12,37 / 13,38 / 13,01 / 15,138 / 15,61 / 17,70 / 19$

2. Government Regulation on the institutional framework of the system for combating irregularities and fraud (AFCOS), Official Gazette 144/13

3. Public Procurement Act, Official Gazette 120/16

4. The Budget Act, Official Gazette 87/2008, 136/12

\section{CJEU CASE LAW}

1. Case C-105/14, Ivo Taricco et al. [2015] ECR, Judgement of the Court (Grand Chamber), 8 September 2015

2. Case C-539/09, European Commission v Federal Republic of Germany, [2011], ECR, Judgment of the Court (Grand Chamber), 15 November 2011

3. Case C-617/10, Aklagaren v Hans Åkerberg Fransson [2013] ECR, Judgment of the Court (Grand Chamber), 26 February 2013

\section{WEBSITE REFERENCES}

1. European Commission, EU Budget 2018, Financial Report, European Union 2019, [https:// ec.europa.eu/info/sites/info/files/about_the_european_commission/eu_budget/financial_ report_web.pdf], accessed 18. May 2020

2. European Commission, OLAF, Fraud in Public Procurement; A collection of Red Flags and Best Practices, Ref. Ares(2017)6254403 - 20/12/2017, [https://ec.europa.eu/sfc/sites/ sfc2014/files/sfc-files/Fraud\%20in\%20Public\%20Procurement_final\%2020.12.2017\%20 ARES\%282017\%296254403.pdf], accessed 25. May 2020 
3. European Commission, Public Procurement, [https://ec.europa.eu/info/sites/info/files/file_ import/european-semester_thematic-factsheet_public-procurement_en_0.pdf], accessed 25. May 2020

4. European Council, Own resources for 2014-2020, [https://www.consilium.europa.eu/en/policies/eu-budgetary-system/eu-revenue-own-resources/2014-2020/], accessed 26. May 2020

5. Ferro, M. S., ECJ on Taricco II: a game changer? The primacy and effectiveness of EU law take a serious hit, 2017, [https:/www.linkedin.com/pulse/ecj-taricco-ii-game-changer-primacy-effectiveness-eu-law-sousa-ferro/], accessed 27. May 2020

6. Parry, M.; Sapala, M., Post-2020 MFF and own resources, Ahead of the Commission's proposal, [https://www.europarl.europa.eu/RegData/etudes/BRIE/2018/620240/EPRS_ BRI(2018)620240_EN.pdf], accessed 18. May 2020

7. Position of the European Parliament adopted at first reading on 16 April 2014 with a view to the adoption of Directive 2014/.../EU of the European Parliament and of the Council on the fight against fraud to the Union's financial interests by means of criminal law, [https:/www. europarl.europa.eu/sides/getDoc.do?pubRef=-//EP//TEXT+TA+P7-TA-2014-0427+0+$\mathrm{DOC}+\mathrm{XML}+\mathrm{V0} / / \mathrm{EN}]$, accessed 18. May 2020

8. Presidency and Croatia, [https://eu2020.hr/Home/Custom?code=CroatiaEU], accessed 15. May 2020

9. Report from the Commission to the European Parliament and the Council based on Article 10 of Council Framework Decision 2008/841/JHA of 24 October 2008 on the fight against organised crime, [https://eur-lex.europa.eu/legal-content/EN/TXT/PDF/?uri=CELEX:52016DC0448\&from=HR], accessed 27. May 2020

10. Report on Budgetary and Financial Managment of the European Commission, Section III of the Budget, Report pursuant to Art 249 of the financial Regulation for the financial year 2019, [https://www.europarl.europa.eu/RegData/etudes/BRIE/2018/620240/EPRS_ BRI(2018)620240_EN.pdf], accessed 20. May 2020

11. Sapala, M., Multiannual Financial Framework for the years 2021-2027 and the New Own Resources, [https://ec.europa.eu/commission/publications/factsheets-long-term-budget-proposals_en], accessed 18. May 2020

12. The Draft Act to Amend the Criminal Code, 2018, [https://esavjetovanja.gov.hr/ECon/ MainScreen?entityId=7635], accessed 25. May 2020 